\title{
Androgen receptor in satellite cells is not essential for muscle regenerations
}

\author{
Hiroshi Sakai $^{1,2}$ (D), Takahiko Sato ${ }^{3}$, Motoi Kanagawa ${ }^{4}$, So-ichiro Fukada ${ }^{5}$ and Yuuki Imai ${ }^{1,2,6, *}$ \\ ${ }^{1}$ Division of Integrative Pathophysiology, Proteo-Science Center, Ehime University, Toon, Ehime 791-0295, Japan., \\ ${ }^{2}$ Department of Pathophysiology, Graduate School of Medicine, Ehime University, Toon, Ehime 791-0295, Japan., \\ ${ }^{3}$ Department of Anatomy1, School of Medicine, Fujita Health University, Toyoake, Aichi 470-1192, Japan., ${ }^{4}$ Division of \\ Molecular Brain Science, Kobe University Graduate School of Medicine, Kobe, Hyogo 650-0017, Japan, ${ }^{5}$ Project for Muscle \\ Stem Cell Biology, Graduate School of Pharmaceutical Sciences, Osaka University, Suita, Osaka 565-0871, Japan, and ${ }^{6}$ Division \\ of Laboratory Animal Research, Advanced Research Support Center, Ehime University, Toon, Ehime 791-0295, Japan \\ *Corresponding author. E-mail: y-imai@m.ehime-u.ac.jp
}

(Received 17 January 2020; Revised 21 February 2020; Accepted 27 February 2020)

\begin{abstract}
The anabolic effects of androgen on skeletal muscles are thought to be mediated by androgen receptor (AR). Although multiple studies concerning the effects of AR in males have been performed, the molecular mechanisms of AR in skeletal muscles remain unclear. Here we first confirmed that satellite cells from mouse hindlimb muscles express AR. We then generated satellite cell-specific AR knockout mice using Pax $7^{\text {CreERT2 }}$ and $A R^{L 2 / Y}$ mice to test whether AR in satellite cells is necessary for muscle regeneration. Surprisingly, we found that muscle regeneration was compromised in both Pax $7^{\mathrm{CrEERT2}(\mathrm{Fann}) /+}$ control mice and Pax $7^{\mathrm{CreERT2}}$ ${ }_{(\text {Fan }) /+} ; A R^{L 2 / Y}$ mice compared to $A R^{L 2 / Y}$ mice. However, $\operatorname{Pax} 7^{\text {CreERT2(Gaka)/+}} ; A R^{L 2 / Y} ; R 26^{\text {tdTomato/+ }}$ mice showed no significant differences between control and mutant muscle regeneration. These findings indicate that AR in satellite cells is not essential for muscle regeneration. We propose that $\operatorname{Pax} 7^{\mathrm{CreERT2(Fan)/+}}$ control mice should be included in all experiments, because these mice negatively affect the muscle regeneration and show the mild regeneration phenotype.
\end{abstract}

Keywords: androgen receptor; skeletal muscle; satellite cells; muscle regeneration (minimum 3, maximum 5)

\section{Introduction}

Regenerative capacity of adult skeletal muscles is mediated by muscle stem cells, termed satellite cells (Lepper et al., 2011; Murphy et al., 2011; Sambasivan et al., 2011), which express the transcription factor Pax7 (Seale et al., 2000). Sex hormones, including androgens, are thought to play an important role in satellite cell function during muscle development and repair after injury (Kim et al., 2016). However, the molecular mechanisms by which androgen receptor (AR), a member of the nuclear receptor superfamily, might regulate satellite cells remain poorly understood.

Although Dubois described mice having satellite cell-specific knockout of AR (Dubois et al., 2014), they used MyoD-iCre mice in which the MyoD locus was active through satellite cell development and ARs were inactivated prenatally in satellite cell progenitors and all MyoD-positive myoblasts during development. To our knowledge, there are no studies that examined whether AR plays important roles in satellite cells during muscle regeneration using satellite cells-specific knock-out mice of AR in adults.

\footnotetext{
(C) The Author(s) 2020. This is an Open Access article, distributed under the terms of the Creative Commons Attribution licence (http:// creativecommons.org/licenses/by/4.0/), which permits unrestricted re-use, distribution, and reproduction in any medium, provided the original work is properly cited.
} 


\section{Objective}

Here we sought to characterize the role of $\mathrm{AR}$ in muscle satellite cells during muscle regeneration. We tested the hypothesis that AR regulates satellite cell function during activation or differentiation in mice using two types of a tamoxifen-inducible Cre loci at Pax7, Pax $7^{\mathrm{CreERT2}(\mathrm{Fan}) /+}$ and Pax $7^{\mathrm{CreERT2}(\mathrm{Gaka}) /+}$, which were crossed with $A R^{L 2 / Y}$ mice to generate mice having satellite cell-specific AR knockout.

\section{Methods}

\section{Animals}

Pax $7^{\mathrm{CreERT2}(\mathrm{Fan}) /+}, \mathrm{Pax}^{\mathrm{CreERT2}(\mathrm{Gaka}) /+}$ and $R 26^{\text {tdTomato/+ }}$ (Madisen et al., 2009) mice were from Jackson Laboratories (Stock No: 012476, 017763 and 007908, respectively). $A R^{L 2 / Y}$ mice were previously described (Matsumoto et al., 2003). Tamoxifen (150 $\mu \mathrm{l} \mathrm{of} 20 \mathrm{mg} / \mathrm{ml}$; Sigma, T5648) was injected intraperitoneally on 5 consecutive days. We induced muscle injury by cardiotoxin injection $(100 \mu \mathrm{l}$ of $10 \mu \mathrm{M}$; Latoxan, L8102) in the left tibialis anterior (TA) muscle under anesthesia. The Ehime University Animal Experiment Committee approved the animal protocols.

\section{Immunofluorescence and microscopy}

For immunofluorescence staining (protocol: http://dx.doi.org/10.17504/protocols.io.sujeeun), muscles were frozen in liquid nitrogen-chilled isopentane. BIOREVO (Keyence) and Fiji software (https://imagej. net/Fiji) were used to photograph stained tissues and quantify Pax7+ nuclei and Myh3+ muscle fibers.

\section{Satellite cell isolation}

Hindlimb muscle satellite cells were isolated as described (Liu et al., 2015).

\section{Quantitative real-time PCR}

Using a RNeasy Plus Micro Kit (Qiagen, 74034) we extracted satellite cell total RNA for synthesis of cDNA with PrimeScript (Takara, RR036A). We performed duplicate qPCR using TB Green Premix Ex Taq II (Takara, RR820S) and Thermal Cycler Dice (Takara, TP850).

\section{Statistics}

Data were analyzed using Prism 8 (GraphPad Software). Welch's t test (for 2 groups) and Bonferroni's multiple comparisons test (for 3 groups) was used.

\section{Results}

Nearly all Pax7+ cells in control uninjured TA muscle stained positively with AR antibodies, indicating AR expression by satellite cells (Figure 1A). In $\operatorname{Pax} 7^{\mathrm{CreERT2(Fan)/+}} ; A R^{L 2 / Y}$ mice having conditional AR deletion, AR mRNA levels in FACS-isolated satellite cells were decreased relative to control $\left(\mathrm{Pax} 7^{+/+}\right.$; $A R^{L 2 / Y}$ ) mice (Figure 1B).

Surprisingly, upon muscle injury, the number of Pax7+ cells decreased by similar amounts in $\operatorname{Pax} 7^{\mathrm{CreERT2}(\mathrm{Fan}) /+}$ control mice and $\operatorname{Pax} 7^{\mathrm{CreERT2}(\mathrm{Fan}) /+} ; A R^{L 2 / Y}$ mice at $5 \mathrm{dpi}$ (Figure $1 \mathrm{C}$-E), while $\operatorname{Pax} 7^{\mathrm{CreERT2}(\mathrm{Fan}) /+}$ control mice showed slightly delayed muscle regeneration at $14 \mathrm{dpi}$ (Figure $1 \mathrm{~F}-\mathrm{H}$ ).

Pax ${ }^{\text {CreERT2(Gaka)/+ }} ; A R^{L 2 / Y} ; R 26^{\text {tdTomato/+ }}$ mice having different Cre-mediated AR deletions in satellite cells (Figure 2A) had similar numbers of Pax7+ cells at $5 \mathrm{dpi}$ as the control (Figure 2B-D). Muscle regeneration in terms of Myh3+ fiber numbers was similar for the control and mutant mice at $14 \mathrm{dpi}$ 
A
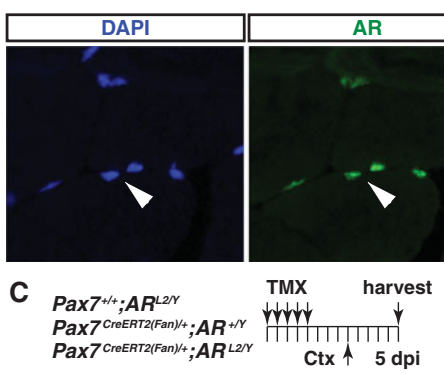

D

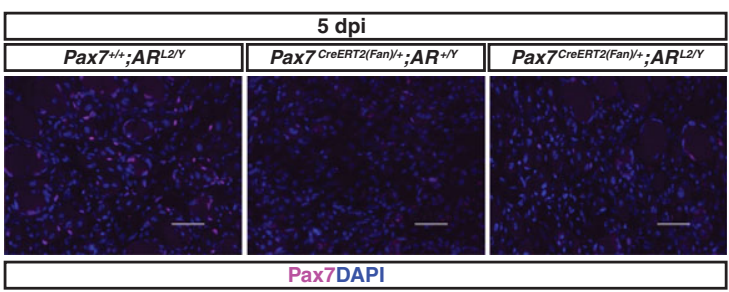

Pax7DAPI
B

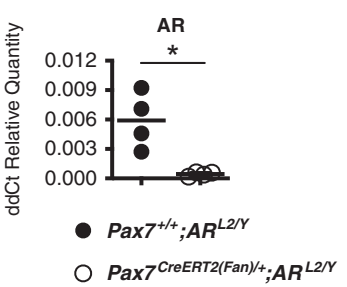

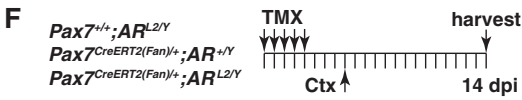

G

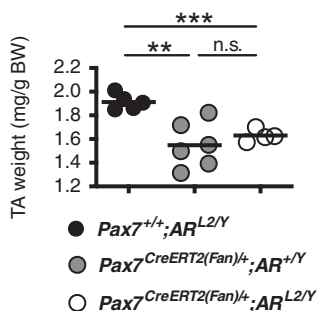

H

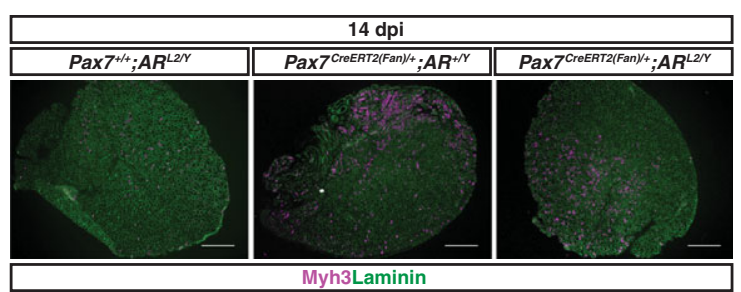

I

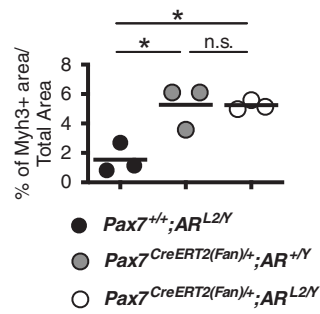

Figure 1. Pax $7^{\text {(reERT2(Fan)/4 }}$ mice show a substantial decrease in the number of Pax $7+$ cells during muscle regeneration. (A) AR and Pax7 immunofluorescence in uninjured TA muscle. Arrowheads indicate double positive cells. Scale bar $=20 \mu \mathrm{m}$. (B) RT-qPCR of AR in satellite cells from control $\left(\operatorname{Pax}^{+/+} ; A R^{L 2 / Y}\right)$ and mutant $\left(\operatorname{Pax} 7^{\mathrm{CreERT2}(\mathrm{Fann}) /+} ; A R^{L 2 / Y}\right)$ mice $(\mathrm{n}=4)$. (C) Scheme for experiments at 5 dpi. (D) Immunofluorescence of Pax7 in TA muscle at $5 \mathrm{dpi}$. Scale bar $=50 \mu \mathrm{m}$. (E) Quantification of the number of Pax7+ cells. (F) Scheme for experiments at $14 \mathrm{dpi}$. (G) TA muscle mass at $14 \mathrm{dpi}$. (H) Myh3 and laminin immunofluorescence in TA muscles at $14 \mathrm{dpi}$. Scale bar $=500 \mu \mathrm{m}$. (I) Quantification of the number of Myh3+ cells $(n=3)$ at 14 dpi. n.s., not significant, ${ }^{\star} p<0.05,{ }^{\star \star} p<0.01,{ }^{\star \star \star} p<0.001,{ }^{\star \star \star \star} p<0.0001$. BW, body weight; Ctx, cardiotoxin; dpi, days post injury; TA, tibialis anterior; TMX, tamoxifen.

(Figure 2E-G). Together, these results suggest that AR expressed by satellite cells is not involved in muscle regeneration.

\section{Discussion}

The Pax ${ }^{\operatorname{CreERT2(Fan)/+}}$ regeneration phenotype is consistent with previous findings (Mademtzoglou et al., 2018) and likely related to expression of only one Pax7 allele after CreERT2 insertion (Lepper et al., 2009). Leaky Cre recombinase activation and downregulation of Heyl, which is required to maintain satellite cells, in Pax $7^{\mathrm{CreERT2}(\mathrm{Fan}) /+}$ mice not treated with tamoxifen (Noguchi et al., 2019) could affect satellite cells during muscle regeneration.

The muscle regeneration activity seen in satellite cell-specific AR knockout mice despite effective AR deletion suggests that AR does not function in muscle regeneration. However, a phenotype that was not detectable in our assays might be present. 


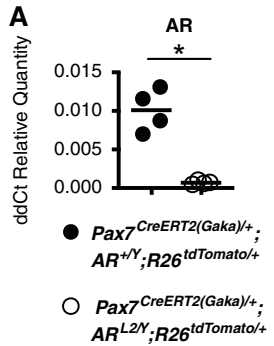

E

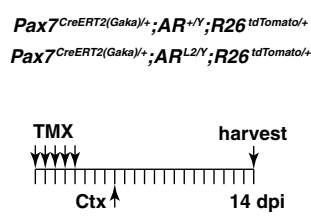

B

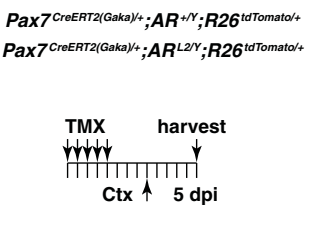

F

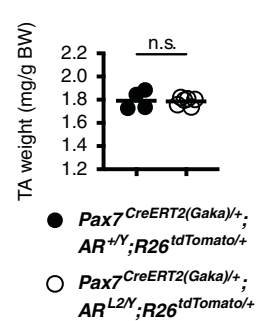

C

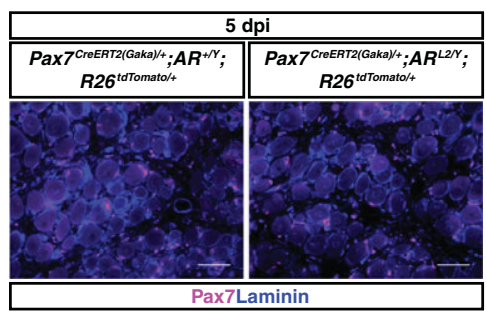

G

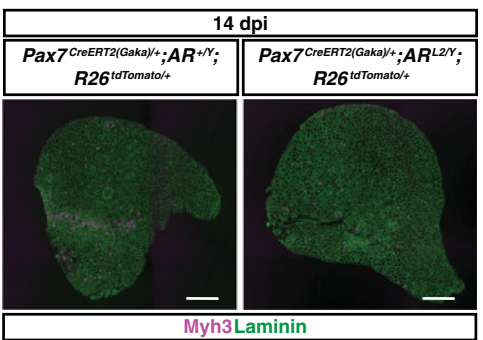

D

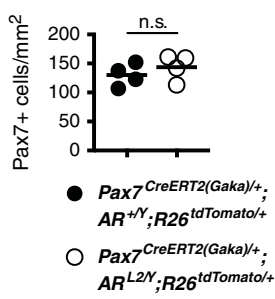

H

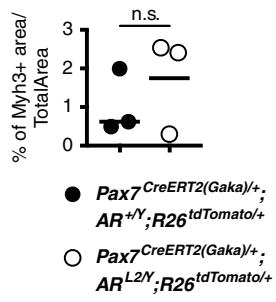

Figure 2. Androgen receptor is not required for satellite cells to regenerate muscle. (A) RT-qPCR of AR in satellite cells from control (Pax $\left.7^{\text {CreERT2 (Gaka)/+ }} ; A^{+/ Y} ; R 26^{\text {tdTomato } /+}\right)$ and mutant $\left(P a x 7^{\text {CreERT2(Gaka)/+ }} ; A R^{L 2 / Y} ; R 26^{\text {tdTomato } /+}\right)$ mice $(\mathrm{n}=4)$. (B) Scheme for experiments at $5 \mathrm{dpi}$. (C) Immunofluorescence of Pax7 and laminin in TA at $5 \mathrm{dpi}$. Scale bar $=50 \mu \mathrm{m}$. (D) Quantification of the number of Pax7+ cells $(n=4)$. (E) Scheme for experiments at $14 \mathrm{dpi}$. (F) TA muscle mass at $14 \mathrm{dpi}(\mathrm{n}=4$ for control, $n=5$ for mutant). (G) Myh3 and laminin immunofluorescence in TA muscles at $14 \mathrm{dpi}$. Scale bar $=500 \mu \mathrm{m}$. (H) Quantification of the number of Myh3+ cells $(n=3)$ at 14 dpi. n.s., not significant, ${ }^{*} p<0.05$, BW, body weight; Ctx, cardiotoxin; dpi, days post injury; TA, tibialis anterior; TMX, tamoxifen.

\section{Conclusions}

Our muscle regeneration experiments using Pax $7^{\operatorname{CrEERT2}(F a n) /+}$ mice suggest that these Cre mice, especially gene Knockout/Knockin mice, must be used carefully and in combination with other Cre mice to avoid the problem of "pseudo phenotypes" generated by the Cre cassette or Cre insertion at the target locus. Our data for $\operatorname{Pax} 7^{\mathrm{CreERT2(Gaka)/+}} ; A R^{L 2 / Y} ; R 26^{\text {tdTomato/+ }}$ mice demonstrated that AR expression by satellite cells is not necessary for muscle regeneration in adults.

Acknowledgements. We thank S. Nakanishi and A. Nishio for technical support and K. Kameda at the Division of Analytical Bio-Medicine in the Advanced Research Support Center (ADRES) of Ehime University for flow cytometry support.

Author Contributions. HS and YI designed the study and wrote the manuscript. HS performed the experiments and analyzed the data. TS, MK, and SF provided materials.

Funding Information. This work was supported in part by MEXT/JSPS KAKENHI (H.S., 18H06439, 19K19947), (Y.I., 17H6427, 19H03786); The Nakatomi Foundation (Y.I.), Takeda Science Foundation (Y.I.), the Osaka Medical Research Foundation For Intractable Diseases (H.S., H30 2-18); and the Ehime University Grant-in-Aid Research Empowerment Program (H.S., H30 Start-up Support).

Data Availability Statements. The data that support the findings of this study are openly available in protocols.io at http:// dx.doi.org/10.17504/protocols.io.sujeeun.

Conflicts of Interest:. Hiroshi Sakai, Takahiko Sato, Motoi Kanagawa, So-ichiro Fukada and Yuuki Imai have no conflicts of interest to declare.

\section{References}

Dubois, V., Laurent, M. R., Sinnesael, M., Cielen, N., Helsen, C., Clinckemalie, L., Spans, L., Gayan-Ramirez, G., Deldicque, L., Hespel, P., Carmeliet, G., Vanderschueren, D., \& Claessens, F. (2014). A satellite cell-specific knockout of the androgen 
receptor reveals myostatin as a direct androgen target in skeletal muscle. The FASEB Journal, 28, 2979-2994. https://doi.org/ 10.1096/fj.14-249748.

Kim, J.-H., Han, G.-C., Seo, J.-Y., Park, I., Park, W., Jeong, H.-W., Lee, S., Bae, S., Seong, J., Yum, M.-K., Hann, S.-H., Kwon, Y.-G., Seo, D., Choi, M., \& Kong, Y.-Y. (2016). Sex hormones establish a reserve pool of adult muscle stem cells. Nature Cell Biology, 18, 930-940. https://doi.org/10.1038/ncb3401.

Lepper, C., Conway, S. J., \& Fan, C.-M. (2009). Adult satellite cells and embryonic muscle progenitors have distinct genetic requirements. Nature, 460, 627. https://doi.org/10.1038/nature08209.

Lepper, C., Partridge, T. A., \& Fan, C.-M. (2011). An absolute requirement for Pax7-positive satellite cells in acute injuryinduced skeletal muscle regeneration. Development, 138, 3639-3646. https://doi.org/10.1242/dev.067595.

Liu, L., Cheung, T. H., Charville, G. W., \& Rando, T. A. (2015). Isolation of skeletal muscle stem cells by fluorescence-activated cell sorting. Nature Protocols, 10, 1612-1624. https://doi.org/10.1038/nprot.2015.110.

Mademtzoglou, D., Asakura, Y., Borok, M. J., Alonso-Martin, S., Mourikis, P., Kodaka, Y., Mohan, A., Asakura, A., \& Relaix, F. (2018). Cellular localization of the cell cycle inhibitor Cdkn1c controls growth arrest of adult skeletal muscle stem cells. ELife, 7, e33337. https://doi.org/10.7554/elife.33337.

Madisen, L., Zwingman, T. A., Sunkin, S., Oh, S., Zariwala, H. A., Gu, H., Ng, L. L., Palmiter, R. D., Hawrylycz, M. J., Jones, A. R., Lein, E. S., \& Zeng, H. (2009). A robust and high-throughput Cre reporting and characterization system for the whole mouse brain. Nature Neuroscience, 13, 133-140. https://doi.org/10.1038/nn.2467.

Matsumoto, T., Takeyama, K., Sato, T., \& Kato, S. (2003). Androgen receptor functions from reverse genetic models. The Journal of Steroid Biochemistry and Molecular Biology, 85, 95-99. https://doi.org/10.1038/nn.2467.

Murphy, M. M., Lawson, J. A., Mathew, S. J., Hutcheson, D. A., \& Kardon, G. (2011). Satellite cells, connective tissue fibroblasts and their interactions are crucial for muscle regeneration. Development, 138, 3625-3637. https://doi.org/10.1242/ dev.064162.

Noguchi, Y., Nakamura, M., Hino, N., Nogami, J., Tsuji, S., Sato, T., Zhang, L., Tsujikawa, K., Tanaka, T., Izawa, K., Okada, Y., Doi, T., Kokubo, H., Harada, A., Uezumi, A., Gessler, M., Ohkawa, Y., \& Fukada, S. (2019). Cell-autonomous and redundant roles of Heyl and HeyL in muscle stem cells: HeyL requires Hes 1 to bind diverse DNA sites. Development, 146, pii: dev163618. https://doi.org/10.1242/dev.163618.

Sambasivan, R., Yao, R., Kissenpfennig, A., Wittenberghe, L., Paldi, A., Gayraud-Morel, B., Guenou, H., Malissen, B., Tajbakhsh, S., \& Galy, A. (2011). Pax7-expressing satellite cells are indispensable for adult skeletal muscle regeneration. Development, 138, 3647-3656. https://doi.org/10.1242/dev.067587.

Seale, P., Sabourin, L. A., Girgis-Gabardo, A., Mansouri, A., Gruss, P., \& Rudnicki, M. A. (2000). Pax7 is required for the specification of myogenic satellite cells. Cell, 102, 777-786. https://doi.org/10.1016/s0092-8674(00)00066-0.

Cite this article: Sakai H, Sato T, Kanagawa M, Fukada S-i, Imai Y (2020). Androgen receptor in satellite cells is not essential for muscle regenerations Experimental Results, 1, e21, 1-9. https://doi.org/10.1017/exp.2020.14 


\title{
Peer Reviews
}

\section{Reviewing editor: Prof. Martin Michaelis}

University of Kent, School of Biosciences, Canterbury, United Kingdom of Great Britain and Northern Ireland, CT2 7NJ

This article has been accepted because it is deemed to be scientifically sound, has the correct controls, has appropriate methodology and is statistically valid, and met required revisions.

\section{doi:10.1017/exp.2020.14.pr1}

\section{Review 1: Androgen receptor in satellite cells is not essential for muscle regeneration}

\author{
Reviewer: Dr. Mark Wass
}

University of Kent, Biosciences, Canterbury, United Kingdom of Great Britain and Northern Ireland, CT2 7NZ

Date of review: 08 February 2020

Published online:

(C) The Author(s) 2020 This is an Open Access article, distributed under the terms of the Creative Commons Attribution licence http://creativecommons.org/licenses/by/4.0/), which permits unrestricted re-use, distribution, and reproduction in any medium, provided the original work is properly cited.

Conflict of interest statement. Reviewer declares none.

\section{Comment}

Comments to the Author: This manuscript reports a study to investigate the role of the androgen receptor on muscle satellite cell regeneration. Performing a mouse study they find that the androgen receptor does not have a role in this process. The work seems to have been performed in suitable way and I think this is suitable for publication in Experimental Results.

\section{Score Card}

Presentation

4.0

Is the article written in clear and proper English? (30\%)

Is the data presented in the most useful manner? (40\%)

Does the paper cite relevant and related articles appropriately? (30\%)

\section{Context}

Does the abstract correctly embody the content of the article? (25\%)

Does the introduction give appropriate context? (25\%)

Is the objective of the experiment clearly defined? (25\%) 
Are the limitations of the experiment as well as the contributions of the experiment clearly outlined? $(20 \%)$ 


\title{
Review 2: Androgen receptor in satellite cells is not essential for muscle regeneration
}

\author{
Reviewer: Dr. Gabrielle Kardon (1)
}

University of Utah School of Medicine, Human Genetics, 15 North 2030 East, Salt Lake City, Utah, United States, 84112

Date of review: 21 February 2020

Published online:

(C) The Author(s) 2020 This is an Open Access article, distributed under the terms of the Creative Commons Attribution licence http://creativecommons.org/licenses/by/4.0/), which permits unrestricted re-use, distribution, and reproduction in any medium, provided the original work is properly cited.

Conflict of interest statement. No conflict

\section{Comment}

Comments to the Author: This paper tests the role of the androgen receptor (AR) in satellite cells (SCs) for muscle regeneration by conditionally deleting AR in SCs with two Pax7CreERT2 alleles: the Fan allele is a knock-in/knock-out and is heterozygous for Pax7 and the GAKA allele which keeps both copies of Pax7 intact. They found that the Pax7CreERT2(Fan) alone caused a decrease in TA weight and an increase in embryonic myosin. Also they show that AR deletion did not result in a further phenotype as compared with mice with just Pax7CreERT2(Fan). Consistent with this, AR deletion with Pax7CreERT2(GAKA) has no phenotype. They conclude that AR is not required in SCs for muscle regeneration. Also, the heterozygosity for Pax7 in Pax7CreERT2(Fan) mice is deleterious for regeneration. Overall, these data are important results. A few suggestions:

1. It is an important result that the Pax7CreERT2(Fan) mice negatively impacts regeneration and should be highlighted in the abstract and title.

2. The introduction describes the Dubois et al. 2014 paper as a SC-specific knockout of AR, but this is a knock-out in all MyoD+ myoblasts in development onward. They authors' paper is the first true conditional knock-out of AR in SCs - a distinction they should make clear.

3. Indicate if Fig $1 \mathrm{~A}$ experiments were conducted on uninjured or injured muscle. If injured, how many days post injury?

4. Quantify and statistically analyze amount of Myh3 in all genotypes.

5. Statistically analyze differences in Pax7+ cells and weight between Pax7CreERT2(Fan)/+;Ar+Y versus Pax7CreERT2(Fan)/+;ArL2/Y and between Pax7CreERT2(GAKA)/+;Ar+Y versus Pax7CreERT2(GAKA)/+;ArL2/Y.

\section{Score Card}

Presentation 
Does the abstract correctly embody the content of the article? (25\%) 3/5

Does the introduction give appropriate context? (25\%) 2/5

Is the objective of the experiment clearly defined? (25\%) $1 / 5$

Analysis

Does the discussion adequately interpret the results presented? (40\%)

Is the conclusion consistent with the results and discussion? (40\%)

Are the limitations of the experiment as well as the contributions of the experiment clearly outlined? (20\%) 